\title{
Central cretinism in four successive siblings
}

\author{
U.P. Isichei, S.C. Das and J.O. Egbuta
}

Department of Clinical Chemical Pathology, Faculty of Medical Sciences, University of Jos, Jos, Nigeria.

\begin{abstract}
Summary: A study of four successive siblings, age 9, 12, 14 and 16 years with cretinism associated with congenitial central hypothyroidism (central cretinism), born to a mother in the endemic goitre region of the Jos Plateau, Nigeria, is presented. Biochemically, the defects were characterized by abnormally low basal thyroxine, triiodothyronine and thyroid stimulating hormone, as well as refractory TSH response to thyrotrophin releasing hormone and gross hyperlipidaemia. Clinically, the intellectual, physical and neurological impairment varied from moderate in the youngest to very severe in the oldest. Contrasting clinical pictures of cretinism, which appeared related to age and previous treatment were found with a spectrum ranging from predominantly myxoedematous in the youngest to predominantly neurological in the 16 year old male. Response to adequate treatment was dramatic, with restoration of severe gait disturbance occurring almost completely, but the imprints of thyroid hormone deficiency on mental defects and intellectual performance remained almost unaltered. The parents and two older sisters were normal with normal thyroid function.
\end{abstract}

\section{Introduction}

Although some salient characteristics of endemic cretinism $^{1-7}$ have been described, more studies appear to be necessary to obtain a clearer picture of the variants and spectrum of abnormalities caused by fetal and neonatal hypothyroidism in this disease. Epidemiological and clinical studies in the Congo $^{5}$, Zaire and Vietnam ${ }^{6}$ and more recently in Qinghai, China ${ }^{7}$ appear to indicate that thyroid stimulating hormone (TSH) levels in endemic cretinism vary from normal to highly elevated values; the hypothalamic-pituitary-thyroid (HPT) axis is considered intact in the neurological form of the disease. ${ }^{8}$

Congenital hypothyroidism due to loss of hypothalamic-pituitary control is regarded as a rare occurrence being found in 1 out of 100,000 births. ${ }^{9}$ In the present report, we present four successive siblings with congenital hypothyroidism, refractory TSH response to thyroid releasing hormone (TRH), as well as typical clinical features of cretinism (central cretinism). These cases, who were born to the same parents, were found in our thyroid disease survey of the endemic region of the Jos Plateau, Nigeria ${ }^{10}$ Both parents and two eldest daughters are normal with normal thyroid function.

Correspondence: U.P. Isichei, M.D.

Accepted: 4 April 1990

\section{Case reports}

The patients are four children aged 9, 12, 14 and 16 years respectively, comprising two brothers and two sisters. (Figure 1) They were referred to us for investigation at the thyroid study unit of the Clinical Biochemistry Section of the Department of Clinical Chemical Pathology, Faculty of Medical Sciences, Jos University Teaching Hospital.

According to the mother, who is a fairly educated lady, her own parents came originally from Southern Nigeria, but settled many years ago in the tin-mining endemic region of Plateau State in the northern part of the country. Her first two daughters were normal. She noticed subsequently that her third child, a boy, who was born in another town situated only about $30 \mathrm{~km}$ away, was rather sluggish and shorter than other babies of equivalent age in the village. On the advice of the local doctor, the child was given thyroid tablets. She observed each of the next three children, who had identical problems, each time for about 8 months before seeing the doctor for the same reason. She could neither give the children the full dose of tablets prescribed nor provide regular maintenance dose, due to increasing difficulty in obtaining the recommended tablets. No tablets had been administered for 8 months, according to her, prior to the present referral. No obvious neck swelling was noticed by the mother in any of the children since birth. The 14 year old girl had menarche at 12. Menses were at first irregular but are now 


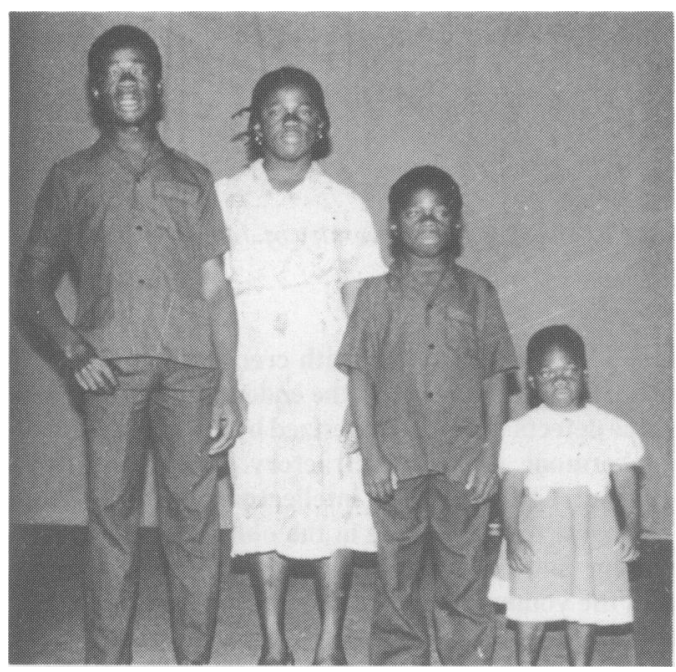

Figure 1 Four successive siblings with central cretinism, low basal thyroid hormone and TSH levels and refractory TSH response to TRH. The parents and two older sisters are normal with normal thyroid function.

regular with a 4-5/28 days' cycle. There was nothing in the family history to suggest any genetic predisposition to thyroid disease. The diagnosis of diabetes mellitus was made for the mother, 10 months after the birth of the fifth child, though she may have been diabetic well before then. Both parents and two eldest sisters are physically and mentally well.

The four agoitrous children were aged 9-16 years, with varying degrees of physical, intellectual and neurological abnormalities. Pulse rates were generally retarded. The characterisitic cretinous facies, dry skin, and large protruding tongues were typical. Some degree of hearing loss and dysarthria was present, especially in the two eldest children. Impairment of growth was only moderate in the two oldest, but severe in the last two children. Mental deficit varied according to age, but ranged from moderate to severe, with the 16 year old exhibiting infantile intelligence; responses to preselected questions were bizarre. Knee jerks were generally hyperactive. The stance and gait were both abnormal in all four and the latter severely restricted and shuffling in the 16 year old boy.

\section{Laboratory Investigations}

Blood samples were collected from all four children during the first visit to the hospital for the determination of basal serum total thyroxine (T4), triiodothyronine (T3), thyroxine binding globulin (TBG) and thyroid stimulating hormone (TSH).
Other parameters determined were serum total lipid and cholesterol levels, beta-lipoprotein cholesterol (LDL), beta-lipoprotein, serum triglycerides, thyroglobulin and microsomal antibodies as well as blood glucose values.

A thyrotrophin releasing hormone test was done during the second visit to the hospital after interrupting medication for 10 days. This time both parents and one healthy sister were invited to the hospital for clinical examination, and blood samples collected for baseline thyroid hormone studies. The mother was also subjected to blood glucose investigation. Thyroid growth blocking antibodies (TGBAb), TSH-binding inhibitor immunoglobulins (TBII) and radiological bone maturation studies were not done due to reasons beyond our control.

Clear serum samples were used for all determinations. The thyroid parameters were determined by the enzyme linked immunosorbent assay (ELISA) technique (Boehringer, Mannheim $\mathrm{GmbH}$, W. Germany) - our standard procedure for thyroid function studies, which is based on the principle of competitive protein binding. The lipid parameters were determined with special reagent kits also manufactured by Boehringer. Cholesterol estimation was based on the enzymatic cholesterol oxidase principle. In the ELISA technique for the determination of thyroid profile, the test on each sample was carried out in triplicate and for dup licate analysis to give six different observations on each sample. Variation between two duplicate analyses as determined by Student's ' $t$ ' test, was found to be statistically insignificant at $5 \%$ level of significance. The detection of circulating thyroid antibodies was done by measuring the titre in serum through indirect agglutination. Glucose was measured by the glucose oxidase method.

Control serum samples, which consisted of a Precinorm (Boehringer) and two samples from proven cases of hypothroidism and hyperthyroidism were put through the assay procedure. An internal quality control practice for the ELISA technique was maintained throughout the period of our thyroid disease survey. ${ }^{10}$

On the morning of the TRH test ${ }^{11}$ a basal blood sample was collected from each patient; $200 \mu \mathrm{g}$ of TRH was injected rapidly intravenously. Blood samples were collected at 20 minutes and 60 minutes after the dose. TSH and thyroid hormones were determined in all the serum samples derived from the specimens after centrifugation, caution being observed to avoid haemolysis. The TRH used for this investigation was obtained from Japan through the courtesy of Japan International Cooperation Agency (JICA).

Our laboratory set-up for iodine analysis though appropriate for potable water iodine, was unsuitable for urinary iodide determination and 
consequently urinary iodide levels could not be determined at the time of the investigation of our patients. However, iodine deficiency is common in the region. ${ }^{10}$ The mean range for potable water iodine was $0.001-0.007 \mathrm{ppm}$ and for urinary iodide $3.53-9.04 \mu \mathrm{g} / \mathrm{dl}$ in the 13 districts with varying degrees of endemicity compared to $0.041 \mathrm{ppm}$ and $15.3 \mu \mathrm{g} / \mathrm{dl}$ respectively found at Jos, the goitre-free zone. ${ }^{12}$

\section{Results}

\section{Basal T4 and TSH; TRH-test}

The diagnosis of cretinism due to pituitary or hypothalamic failure was suspected during the first visit of the patients to our unit, on the basis of a low basal TSH found in association with low thyroid hormones and typical clinical signs of cretinism. A partial or selective TSH deficiency was considered in view of the clinical history of normal menstruation, which was at first irregular, as well as the well developed breasts found in the 14 year old girl which appeared to indicate that, at least, some of the pituitary-dependent hormones were probably normal. These hormones were not determined due to lack of appropriate facilities. But as has been pointed out ${ }^{13,14}$ both androgen and oestrogen metabolism are complex in hypothyroid patients, and although serum total testosterone and oestradiol concentrations are decreased because of low sex hormone binding globulin, their absolute free concentration is normal. The basal TSH levels found in the parents and one normal sister who have normal thyroid function, contrast sharply with the values found in the patients (Table I).

The results of the TRH-test which shows very low TSH levels at 20 and 60 minutes in the presence of low serum T4 confirmed the diagnosis of central hypothyroidism. The delayed TSH response to TRH in one of the patients (Table I), suggests that very little functional reserve in the pituitary for TSH is probably present in that patient or that the pathology affects the pituitary as well as the hypothalamus.

A negative impact of thyroxine replacement therapy on TSH is unlikely in our patients as no thyroxine tablets had been administered to them during the 8 months preceding the investigations. Moreover in central hypothyroidism for reasons not yet clear, both basal TSH $^{15,16}$ and the TSH response to TRH ${ }^{17}$ remain moderately or markedly elevated for weeks, months or even years in spite of normal total and free thyroxine and normal physical and intellectual development of the patients.

\section{Plasma lipids}

The gross serum lipid changes in all four patients are evident in Table II. The serum levels of total cholesterol, beta-lipoprotein cholesterol (LDL), beta-lipoprotein and triglyceride were extremely high and in some cases exceeding three-fold the normal levels found in healthy subjects used as the controls.

\section{Antithyroid autoantibodies}

The tests for both thyroglobulin and microsomal antibodies were negative in all the four patients, a pattern which is consistent with the diagnosis of central hypothyroidism.

\section{Discussion}

The occurrence of cretinism due to central hypothyroidism (central cretinism) in four successive siblings in one mother with two previous normal children, is considered not only interesting but a significant finding. Studies carried out in $\mathbf{N}$. America, Europe, Australia and Japan indicate that the incidence of congenital hypothyroidism is subject to geographical ${ }^{1821}$ and seasonal ${ }^{22}$ variations. No reports are as yet available from the African continent though the incidence is said to be lower in blacks compared to Asian infants. ${ }^{33}$

The aggregation of the cases in the family in the present study suggests that a genetic factor may be important aetiologically. Familial cretinism due to dysgenesis of the thyroid (total agenesis, ectopic, hypoplastic) is unlikely in our patients as the patients would otherwise have responded with a markedly raised TSH. Dyshormonogenesis or iatrogenic causes, such as maternal medication with iodine-containing drugs during pregnancy, are also unlikely in view of the lack of evidence of goitre either in the family history or in the patients.

Recent advances in thyroid studies indicate that autoimmune factors, acting alone or in combination with extrinsic factors, affect the function, and probably ontogenesis of the thyroid. The clinical history of repeated pregnancies, in a mother in whom two normal children preceded four consecutive abnormal children, suggests that the contribution of autoimmune factors is not unlikely. The diagnosis of diabetes mellitus after the birth of the fifth child reinforces this statement, and pregnancy is notorious for the onset of both diabetes and thyroid disease. ${ }^{24}$ Antithyroglobulin (ATA) and antimicrosomal (AMA) antibodies ${ }^{25,26}$ thyroid growth blocking receptor antibodies (TGBAb) ${ }^{26-28}$ and TSH-binding inhibitor immunoglobulins ${ }^{28-31}$ have all been implicated in the genesis of congenital hypothyroidism but the exact role of these 
Table I Thyroid function in four successive agoitrous cretinous siblings, their parents and one normal sister in the endemic region of Jos Plateau, N. Nigeria

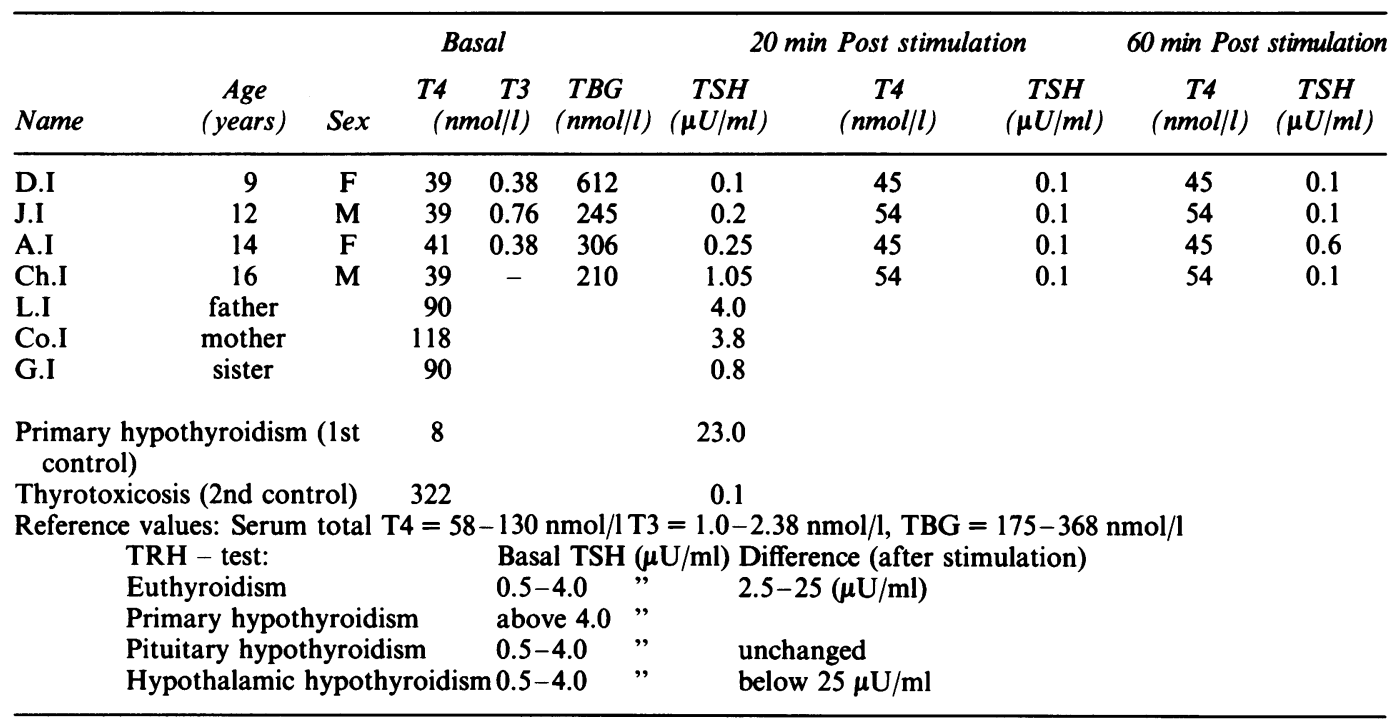

Table II Serum lipids and lipoprotein profiles in four successive siblings with central cretinism

\begin{tabular}{lccccc}
\hline Name & $\begin{array}{c}\text { Age } \\
\text { (years) }\end{array}$ & Sex & $\begin{array}{c}\text { Total cholesterol } \\
(\text { mmol/l) }\end{array}$ & $\begin{array}{c}\text { Beta-lipoprotein } \\
\text { cholesterol (mmol/l) }\end{array}$ & $\begin{array}{c}\text { Beta-lipoprotein } \\
(\mathrm{g} / \mathrm{l})\end{array}$ \\
\hline D.I. & 9 & $\mathrm{~F}$ & 8.1 & 6.0 & 6.7 \\
J.I & 12 & $\mathrm{M}$ & 13.8 & 11.2 & 12.4 \\
A.I & 14 & $\mathrm{~F}$ & 10.4 & 7.7 & 8.6 \\
Ch.I & 16 & $\mathrm{M}$ & 5.8 & 4.3 & 4.8 \\
Co. I (mother) & & & & \\
Reference values (local) & $1.7-5.2$ & $1.6-2.8$ & $1.9-3.15$ \\
\hline
\end{tabular}

immunoglobulins is still not clear. The tests for ATA and AMA were both negative in all our patients. Blocking antibodies are said to induce primary atrophic hypothyroidism, ${ }^{32}$ but our patients have secondary, not primary hypothyroidism. These particular antibodies are, therefore, unlikely to be very relevant to the condition in our present cases. The recent report of the association of pituitary cell antibodies with pituitary hypothyroidism induced by lymphoid hypophysitis ${ }^{33}$ and insulin-dependent diabetes mellitus $^{34}$ is another case in point. Similarly, and perhaps of more significance and relevance to our cases, anti-TSH antibodies were recently found in a case with severe myxoedema. ${ }^{35}$ Finally, comment must also be made on the unusually high immunoglobulins invariably found in association with endemic goitre in subjects with no evidence of infection in our region. ${ }^{36}$ The significance of these vital findings awaits further studies, but, as is clearly evident, they underscore the prominence of immunological events in the development and process of thyroid disease.

The appearance of clinical signs of hypothyroidism in the siblings in the neonatal period, in a region of endemic goitre suggests a pathology of intra-uterine or neonatal aetiology. Infections in utero, such as with rubella or meningitis, or birth injuries, which may cause similar defects, are unlikely in four consecutive births. It is now generally believed that hypothyroidism arising from iodine deficiency is the probable cause of all the neurological injury in cretinism. ${ }^{37}$ Thyroid hormone is important not only for the enhancement of neural cell formation but for the development of synaptic organization and neurotransmitter systems ${ }^{38-39}$ during the critical period of fetal brain development. There is also evidence that the hypothalamo-pituitary axis of the fetus does not attain full maturity until the end of a full term 
pregnancy. ${ }^{40}$ Any insult to the brain before this period could arrest its development. The severe neurological deficits found in the present case are proof of fetal hypothyroidism in the first and early second trimester. The impaired growth and related somatic abnormalities are evidence of thyroid function failure during the third and subsequent postnatal period. It is our view that in our patients, genetic predisposition provided a fertile environment in which pregnancy initiated a chain of events, which was multiplied and expressed in an iodine-deficient environment. The adverse effects of iodine deficiency are compounded by ingested potent goitrogens present in cereals, such as millet, the subsistence crop of the region.

The salient characterisitics of cretinism due to central hypothyroidism (central cretinism) found in the present investigations which deviate from the classical descriptions in either neurological or myxoedematous forms, are the earlier age of onset, the comparatively lower T4 and TSH and refractory TSH response to TRH (Table I and Table III). The amorphous clinical picture, which embodies the spectrum of clinical features, which characterize the neurological and myxoedematous cretinism seen in the four cases, deserve some comments. Whereas the two oldest children with near-normal height present a clinical picture more in line with neurological cretinism, the findings in the last two children with stunted growth conform more with the pattern commonly found in myxoedematous cretinisim or the mixed type (Figure 1). These varying pictures, in our opinion, appear partly related to the unsatisfactory postnatal hormone replacement, which was at first adequate to promote and sustain almost normal growth in the first two children but later became not only inadequate in terms of dosage, but often interrupted due to scarcity, a treatment pattern which finally tapered off to complete withdrawal.

A review of the cases after only 4 months of treatment with thyroxine tablets showed dramatic changes. The gait disturbance, which was particularly severe in the eldest child, had improved considerably. The typical coarse facies had become so much less prominent that we could barely recognize the patients during the subsequent visit; a perceived active growth in height had occurred, but the negative imprints of hormone deficiency on mental outlook and intellectual performance had remained almost unaltered. The clinical improvement made by the youngest child was the most impressive. These findings and observations support the view that myxoedematous cretinism occurs as an addition to neurological cretinism and not in place of it. ${ }^{41}$

Table III Biochemical features of central cretinism and the age of onset compared with corresponding features in neurological, mixed and myxoedematous cretinism.

\begin{tabular}{|c|c|c|c|c|c|c|c|c|}
\hline Place & Features & $\begin{array}{l}\text { Patient } \\
\text { (no.) }\end{array}$ & $\begin{array}{c}\text { Age } \\
\text { (years) }\end{array}$ & $\begin{array}{c}T 4 \\
(n m o l / l)\end{array}$ & $\begin{array}{c}T 3 \\
(\mathrm{nmol} / \mathrm{l})\end{array}$ & $T B G$ & $\begin{array}{c}T S H \\
(\mu U m l)\end{array}$ & Goitre \\
\hline $\begin{array}{l}\text { Jos, Plateau } \\
\text { Nigeria } \\
\text { (Present in- } \\
\text { vestigation) }\end{array}$ & $\begin{array}{l}\text { Central } \\
\text { cretinism }\end{array}$ & 4 & & & & & & \\
\hline \multirow[t]{2}{*}{$\begin{array}{l}\text { Qinghai } \\
\text { China }^{7}\end{array}$} & $\begin{array}{l}\text { Neurological } \\
\text { cretinism }\end{array}$ & 15 & $\begin{array}{c}\overline{\mathrm{X}} 12.5 \\
22.3(9.9)\end{array}$ & $\begin{array}{r}41.8 \\
122.5\end{array}$ & $\begin{array}{r}0.51 \\
(26.3)\end{array}$ & 343 & $\begin{array}{c}0.39 \\
3.9(2.3) \mathrm{mIU}\end{array}$ & + \\
\hline & $\begin{array}{l}\text { Mixed } \\
\text { cretinism }\end{array}$ & 29 & $24.4(11.1)$ & 105.8 & (32.7) & & $28.1(76.5) \mathrm{mIU}$ & +- \\
\hline Vietnam $^{6}$ & $\begin{array}{l}\text { Myxoedematous } \\
\text { Neurological }\end{array}$ & $\begin{array}{l}25 \\
57\end{array}$ & $\begin{array}{c}31.6(12.0) \\
\text { varied }\end{array}$ & $\begin{array}{r}53.9 \\
(56.4\end{array}$ & $\begin{array}{r}(34.7) \\
(6.4)\end{array}$ & & $\begin{array}{c}123.8(112.2) \mathrm{mIU} \\
9.1 \\
(5.8-14.2) \mathrm{mIU}\end{array}$ & $\underset{67 \%}{+-}$ goitrous \\
\hline Zaire $^{6}$ & Myxoedematous & 80 & varied & 5.1 & (2.5) & & $\begin{array}{c}117 \\
(90-152) \mathrm{mIU}\end{array}$ & $9 \%$ goitrous \\
\hline
\end{tabular}

Results are shown as mean \pm s.d. (for age and T4).

\section{References}

1. Report of the Pan American Health Organisation Scientific Group on Research in Endemic Goitre. Pan American Health Organisation Committee on Medical Research, 1963.

2. Hetzel, B.S. Iodine deficiency disorders (IDD) and their eradication. Lancet 1983, ii: 1126-1129.
3. Stanbury, J.B. The neural deficits attending iodine deficiency in man. In: Vichayanant, A., Nitiyanant, W., Eastman, C. Nagataki, S. (eds), Recent Progress in Thyroidology, Crystal House Press, Bangkok, 1987 pp. 20-26. 
4. De Long, C.R., Stanbury, J.B. \& Fierro-Benitez, R. Neurological signs in congenital iodine-deficiency disorder (endemic cretinism). Dev Med Child Neurol 1985, $27: 317$.

5. Delange, F., Ermans, A.M., Vis, H.L. \& Stanbury, J.B. Endemic cretinism in Idjwi Island (Kivu Lake, Republic of Congo), J Clin Endocrinol Metab 1972, 34: 1059-1066.

6. Dan Due, M.D., Thilly, C., Vanderpas, J. et al. Etiology of neurological and myxoedematous cretinism in Vietnam and Zaire. In: Vichayanrat, A., Nitiyanant, W.C., Eastman, C. Nagataki, S. (eds) Recent Progress in Thyroidology. Crystal House Press, Bangkok, 1987 pp. 402-406.

7. Eastman, C.J., \& Phillips, I.W. Clinical manifestations of endemic cretinism in Qinghai, China. In: Alberti, K.G.M.M., Besser, G.M., Bierich, J.R., Burger, H.G., Franchimont, P. \& Hall, R. (eds). Endemic Goitre and Iodine Deficiency Disorders - Aetiology, Epidemiology and Treatment. Bailliere's Clinical Endocrinology and Metabolism. Bailliere Tindall, London, 1988, pp. 727-729.

8. Parades-Suarez, M., Vares-Teran, J., Ramirez, I., Ochoa, C. \& Schally, A.V. Hypothalamic-pituitary-thyroid function in endemic cretinism. In: Meideros-Neto, G., Maciel, R.M.B. \& Halpern, A. (eds). Iodine Deficiency Disorders and Congenital Hypothyroidism. Aché, Sao Paulo, Brasil, 1986, pp. 312-317.

9. Fisher, D.A. Effectiveness of newborn screening programs for congenital hypothyroidism: prevalence of missed cases. Pediatr Clin North Am 1987, 34: 881-890.

10. Isichei, U.P., Das, S.C., Banwo, A.I., Morimoto, I. \& Nagataki, S. Endemic goitre in Plateau State, Nigeria. In: Vichayanrat A., Nitiyanant W., Eastman, C. \& Nagataki, S. (eds) Recent Progress in Thyroidology, Crystal House Press, Bangkok, 1987 pp.. 368-372.

11. Hall, R., Ormston, B.J., Besser, G.M., Cryer, R.J. \& Mckendrick, M. TRH-test. Lancet 1972, ii: 759.

12. Morimoto, I., Isichei, U.P., Das, S.C., Banwo, A.I., Egbuta, J. \& Nagataki, S. Urinary iodine and thiocyanate concentrations among school children in endemic goitre area of Plateau State, Nigeria. Proceedings of the Nigeria-Japan joint conference on Endemic Goitre, Jos, Nigeria. Bhindero Press, Nigeria, 1987, pp. 78-81.

13. Degroot, L.J., Larsen, P.R., Refetaff, S. \& Stanbury, J.B (eds) The Thyroid and its Disease, John Wiley \& Sons, New York, Chichester, Brisbane, Toronto, Singapore, 1984 pp. 561-591.

14. Van Wyk, J.J. \& Grumbach, M. Syndrome of precocious menstruation and galactorrhea in juvenile hypothyroidism. $J$ Pediatr 1960, 57: 416.

15. Guyda, H.J. Therapy of congenital hypothyroidism. Evolution of biochemical parameters. In: Burrow, G.H. \& Dussault, J.H. (eds) Neonatal Thyroid Screening. Raven Press, New York, 1980 pp. 247-261

16. Schultz, R.M., Glassman, M.S. \& MacGillvery, H. Elevated threshold for thyrotropin suppression in congenital hypothyroidism. Am J Dis in Childhood 1980, 134: 19-20.

17. Redmond, G.P. \& Soyka, L.F. Abnormal TSH secretory dynamics in congenital hypothyroidism. $J$ Pediatr 1981, 98: 83-85.

18. Fisher, D.A., Dussault, J.H., Foley, T.P. et al. Screening for congenital hypothyroidism: results of screening one million American infants. $J$ Pediatr 1979, 94: 700-705.

19. Delange, F., Beckers, C., Hofer, R., Konig, M.P., Monaco, F \& Varone, S. Progress report on neonatal screening for congenital hypothyroidism in Europe. In: Burrow, G.N. \& Dussault, J.H. (eds) Neonatal Thyroid Screening. Raven Press, New York, 1980, pp. 107-131.

20. Connelly, J. Australian experience in neonatal thyroid screening 1977-1985. In: Therrell, B.L. (ed.) Advances in Neonatal Screening. Elsevier, Amsterdam, 1987, pp. 31-34.

21. Irie, M., Nakijima, H., Inomata, H. et al. Screening of neonta hypothyroidism in Japan. In: Therrell, B.L. (ed.) Advances in Neonatal Screening, Elsevier, Amsterdam, 1987, 41-47.

22. Miyai, K., Connelly, J.P., Foley, T.P. Jr. et al. An analysis of the variation of incidence of congenital dysgenetic hypothyroidism in various countries. Endocrinol Jpn 1984 , 31: $77-81$.
23. Brown, A.L., Fernhoff, P.M., Milner, J., McEwen, C. \& Elsas, L.S. Racial differences in the incidence of congenital hypothyroidism. J Pediatr 1981, 99: 934-936.

24. Jansson, R., Dahlberg, P.A. \& Karlsson, F.A. Postpartum thyroiditis. In: Alberti, M.G.M.M., Besser, G.M., Bierich J.R., Burger, H.G., Franchimont, P. \& Hall, R. (eds) Bailliere's Clinical Endocrinology \& Metabolism: Hypothyroidism and Goitre. Bailiere Tindall, London, 1988, p. 612.

25. Ritson, E.M., Mahler, H. \& Alveryd, A. Transitory congenital hypothyroidism and maternal thyroiditis. Acta Pediatr Scand 1981, 70: 765-766.

26. Delange, F. Permanent neonatal hypothyroidism. Sporadic congenital hypothyroidism: Autoimmunity. In: Alberti, K.G.M.M., Besser, G.M., Bierich, J.R., Burger, H.G., Franchimont, P. \& Hall, R. (eds) Bailliere's Clinical Endocrinology and Metabolism: Hypothyroidism \& Goitre, Bailliere Tindall, London, 1988, p. 641.

27. Francis, G. \& Riley, W. Congenital familial transien hypothyroidism secondary to transplacental thyrotropinblocking antibodies. Am J Dis Child 1987, 141: 1081-1083.

28. Ginsberg, J., Walfish, P.G., Rafter, D.J., Von Westrop, C. Ehrlich, R.M. Thyrotropin blocking antibodies in the sera of mothers with congenitally hypothyroid infants. Clin Endocrinol 1987, 25: 189-194.

29. Matsuura, N., Yamada, Y., Nohara, Y. et al. Familia neonatal transient hypothyroidism due to maternal TSH binding inhibitor immunoglobulins. N Engl J Med 1980, 303: $738-741$.

30. Ishihara, T., Waseda, N., Ikebuko, K. et al. Predicted case with neonatal transient hypothyroidism due to blocking type thyrotropin binding inhibitor immunoglobulins (TB11) Endocrinologia Japonica 1985, 32: 189-194.

31. Delange, F., Fisher, D.A. \& Glinoer, D. Research in Congenital Hypothyroidism, Plenum Press, New York, 1989.

32. Amino, N. Autoimmunity and hypothroidism. In: Alberti K.G.M.M., Besser, G.M., Bierich, J.R., Burger, H.G., Franchimont, P. \& Hall, R. (eds) Bailliere's Clinical Endocrinolog, \& Metabolism: Hypothyroidism \& Goitre, Bailliere Tindell, London, 1988, p. 612.

33. Josse, R.G. Autoimmune hypophysitis. In: Volpe, (ed.) Autoimmune Thyroid Disease. Marcel Dekker, New York, 1985, pp. 405-526.

34. Mirakian, R., Cudworth, A.G., Bottazzo, G.F. \& Richardson, C.A. Autoimmunity to anterior pituitary cells and the pathogenesis of insulin-dependent diabetes mellitus. Lancet 1982, ii: $755-759$.

35. Cho, B.Y., Lee, H.K., Koh, C.S., Min, H.K. \& Lee, M. In: Vichayanrat, A., Nitiyanant, W., Eastman, C. \& Nagataki, S (eds) Recent Progress in Thyroidology. Crystall House Press, Bangkok, 1986.

36. Isichei, U.P., Egbuta, J.O., Das, S.C., Ezeogu, A. A differential study of the proteins in serum in endemic goitre. Proceedings of the Nigeria - Japan joint conference on Endemic Goitre. Jos Ehindero Press, Nigeria G-5, 1987 , 74-78.

37. De Long, $\mathbf{R}$. Neurological involvement in iodine deficiency disorders. In: Hetzel, B.S., Dunn, J.T. \& Stanbury, J.B. (eds) The Prevention and Control of Iodine Deficiency Disorders. Elsevier, Amsterdam, New York, Oxford, 1987, pp. 49-63.

38. Balazs, R., Lewis, P.D. \& Patel, A.J. Nutritional deficiencies and brain development. In: Faulkner, F. \& Tauner, J.M. (eds) Human Growth, Vol. 3. Bailliere-Tindall, London, 1979, pp. 415-480.

39. Potter, B.J., Mano, M.T., Belling, G.B. et al. Retarded foetal brain development resulting from severe iodine deficiency in sheep. Neuropathol Appl Neurobiol 1982, 8: 303-313.

40. Jost, A. Anterior pituitary function in foetal life. In: Harris, G.W. \& Donovan, V.T. (eds) The Pituitary Gland, Butterworth, London, 1966, pp. 299-324.

41. De Long, R. Research Needs, ICCIDD Inaugural Meeting proceedings. In IDD Newsletter, vol. 2. no. 2. p. 8. 